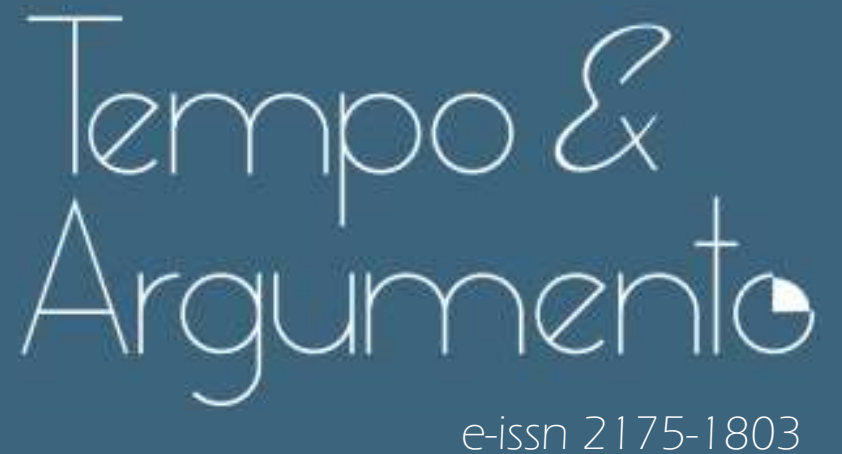

\title{
The international and domestic fabrics of an ideological illusion: the Socialist MPLA
}

\author{
2. Nuno de Fragoso Vidal \\ PhD in Political Science by King's College London. \\ Senior Researcher at the Center for International Studies of the \\ University Institute of Lisbon (CEI-IUL) \\ Lisbon - PORTUGAL \\ cei.iscte-iul.pt/equipa/nuno-vidal/ \\ nunovidal@hotmail.com \\ (D) orcid.org/0000-0002-5921-6311
}

To cite this article (ABNT):

VIDAL, Nuno de Fragoso. The international and domestic fabrics of an

ideological illusion: the Socialist MPLA. Tempo e Argumento, Florianópolis, v.

13, n. 34, e0102, set./dez. 2021.

do http://dx.doi.org/10.5965/2175180313342021 e0102

Received on 26/05/2021

Approved on 17/07/2021 


\title{
The international and domestic fabrics of an ideological illusion: the Socialist MPLA
}

\begin{abstract}
The political-ideological characterization and analysis of Angolan nationalist movements and the conflicts between them, has always been subject of major and passionate political-academic discussion, which became an important component of the nationalist movements' international and domestic characterization and definition. The MPLA (Popular Movement for the Liberation of Angola) rapidly acquired the epithet of leftist, Socialist and Marxist since the anti-colonial struggle through the independence and afterwards. However, during the so-called founding period of an officially proclaimed Socialist MPLA, in an apparent contradiction, the MPLA's governing practice went objectively in an opposite direction, while still reinforcing that unquestioned epithet of Socialist. It is here argued that foreign attributed classifications (political and academic), influenced by the passionate politicalidological struggles of the 1950s, 1960s and 1970s, the civil war and the Cold War, ended up diplomatically-politically assumed (instrumentalised) by the movement itself, whereby an illusive characterization/identification prevailed, hampering a more objective analysis of the post-independence political practice. Our paper will focus on the contrast between the academic discussion on the political-ideological characterization of the MPLA (part I) and the governing practice of the party during the administration of the first President of the Republic, which was the founding period of the MPLA as a so-called Marxist-Leninist Socialist party (part II).
\end{abstract}

Keywords: Angola; MPLA; Socialism; Agostinho Neto administration; political orientation.

\section{A fábrica internacional e doméstica de uma ilusão ideológica: o MPLA Socialista}

\section{Resumo}

A caracterização e análise politico-ideológica dos movimentos nacionalistas Angolanos e dos conflitos entre si, tem sido desde sempre objeto de muitas e apaixonadas discussões político-académicas. Esta caracterização, análise e discussões, tornaram-se uma importante componente da caracterização e definição, internacional e doméstica, dos movimentos nacionalistas. O MPLA (Movimento Popular de Libertação de Angola), rapidamente adquiriu o epíteto de esquerdista, Socialista e Marxista, desde a luta anti-colonial, ao longo do processo de independência, e no pós-independência. Contudo, durante o chamado período de fundação de um oficialmente proclamado MPLA Socialista, numa aparente contradição, a prática governativa do MPLA seguiu objetivamente na direção oposta, não obstante continuar a reforçar aquele ainda assim inquestionado epíteto de Socialista. Este artigo sustenta que aquelas classificações externas (políticas e académicas) atribuídas ao MPLA, influenciadas pelas apaixonadas lutas políticoideológicas das décadas de 1950, 1960 e 1970, a guerra civil e a Guerra Fria, acabaram por ser política-diplomaticamente assumidas (instrumentalizadas) pelo próprio movimento/partido, tendo prevalecido então uma caracterização/identificação ilusória, dificultando uma análise objetiva da prática política do pós-independência. Este artigo centra-se no contraste entre a discussão académica sobre a caracterização político-ideológica do MPLA (parte I) e a prática governativa do partido durante a administração do primeiro Presidente da República, que constituiu o período fundador do MPLA enquanto suposto partido Socialista Marxista-Leninista (parte II).

Palavras-chave: Angola; MPLA; Socialismo; presidência de Agostinho Neto; orientação política. 


\section{Introduction}

The political-ideological characterization and analysis of Angolan nationalist movements and the conflicts between them, has always been subject of major and passionate political-academic discussion, which became an important component of the nationalist movements' international and domestic characterization.

From the anti-colonial struggle through the independence and afterwards, the MPLA rapidly acquired the epithet of leftist, Socialist, Marxist and progressist. However, as shown in this paper, despite such characterization the MPLA's governing practice went objectively in opposite direction during the socalled founding period of an officially proclaimed Socialist MPLA. How was it possible for the MPLA to, domestically and internationally, sustain and reinforce such an unquestioned denomination and at the same time follow in opposite direction in terms of objective policies?

It is here argued that such was the result of an attributed foreign characterization (political-academic) supported by the civil war alignments within the global Cold War framework, as well as by the official discourse of the MPLA itself, which politically instrumentalised such characterization. All these factors hampered a more objective analysis of the post-independence political practice.

As usual in political-ideological characterization processes, it was a dialetic dynamics wherein the construction, modelling and adaptation of the assumed 'image', considered the projected image and expectations that the 'others' had on oneself's image and the effective or expected acceptance/retribution or rejection/punishment one received along the way, as well as the effective political-economic project the governing elites or a section of governing elites had to the new State. A virtuous and successful path as a nationalist movementparty would have to consider these aspects and manage them along the way. That process was therefore pretty much politically-diplomatically instrumentalized (opportunistic) and did not necessarily reflect a commited ideological and sound position as was the case of the MPLA here analysed. 
Nevertheless, the foreign analysis was still unable to question such epithet of Socialist as objectively inadequate.

This paper will focus on the contrast between the academic discussion on the political-ideological characterization of the MPLA (part I) and the governing practice of the party which went in a different direction eventhough camouflaged by the official Socialist discourse (part II). In terms of governing practice, we will concentrate on the administration of the first President of the Republic, which was also the founding period of the MPLA as a so-called Marxist-Leninist Socialist party.

\section{I - The academic contribution for the political-ideological characterization of the MPLA as Socialist.}

For nationalist movements, the international acceptance and support (logistic, diplomatic, and intellectual/academic) was extremely important to get domestic support, because domestic support - popular - was also important to get international recognition, as sociologically representative movements and, consequently, crucial to evalute the capability of the movement to sustainably assume the independent State. It was a dialetic self-reinforcing process to which every nationalist leadearship was attentive.

In this process, the academic political-ideological analysis and characterization of nationalist movements and independentist parties had a major weight, directly impacting on the credibility and legitimacy of the movement's political projects and the support they could raise internationally and domestically.

In terms of Angola, such characterization evolved through three major lines of interpretation, that sequentially set the analytical pace until today. Although in different degrees and varied forms, all of them contributed to the increasingly assumed characterization of the MPLA as Socialist movement/party.

The first, and the earliest line of interpretation, claims that ethno-linguistic cleavages were paramount in Angola, whilst class and ideological differences (although existing) were weak, and that they found direct expression in the three 
nationalist movements that emerged in the 1950s and 1960's - thus impinging on the kind of conflict that arose between them in 1975-1976, namely the civil war. In general terms, these authors stress the weight of an ethno-linguistic-regional explanation under the ideological discourses of a 'leftist' MPLA (relatively more urban and assimilated) and the 'rightists' FNLA and UNITA (relatively more rural and less assimilated by the Portuguese colonial society), identifying the sociological support of the three movements within the three major ethnolinguistic groups as defined during colonialism, approximately encompassing 75\% of the Angolan population - the Ovimbundu from the central plateaux, gathered around UNITA and comprising around 36\% of the population; the M'Bundu from the Luanda-Catete-Malange corridor, gathered around the MPLA and comprising around 27\%; the Bakongo from the North, in the the provinces of Zaire, Uíge and Cabinda, gathered around the UPA/FNLA and comprising around 12\%. These percentages are usually based on 1960 population census of indigenous population of Angola, the last one comprising ethnic identities as defined by the colonial authorities.

Authors such as John Marcum (1969; 1978), René Pelissier (1978), Douglas Wheeler (1970) and Lawrence Henderson (1979) could be included in this category.' Their interpretation, because it was the 'first' and had significant influence, can be considered 'classical' in tracing the sociological origins of each movement and its first political characterization.

The second line of analysis represents a second wave of academic interpretation, and it is the most ideologically influenced. It rejects the importance of the ethno-linguistic factor as a crucial, resorting to class analysis. They are the ones which academically credited and politically supported the MPLA as the progressist, leftist and Socialist movement. This line of analysis was pretty much marked by the stigma of 'redfeet', a term which was made known by Chabal as being used by peasants in Guinea-Bissau for sympathizers with revolution (CHABAL, 1983) and used by Tom Young to expose some deficiencies in the literature on Angola and Mozambique produced for many years before and after independence (YOUNG, 1989). Authors such as Basil Davidson, Fola 
Soremekun, Claude Gabriel, Michael Wolfers \& Jane Bergerol, and Keith Somerville can be included in this category.

Basil Davidson is a staunch supporter of the truly revolutionary impact of the 'people's wars' as exposed in the legitimating speeches of leaders such as Amílcar Cabral and including in this cathegory Agostinho Neto, whom he personally knew and effortedly tried to portrait as such (although that was far from being the case as we will see in part II). These wars would lead to 'real' revolution (after the failures of the first wave of independences in African countries), thereby destroying the ethno-linguistic identification imposed by colonialism on the population, whereby the working masses and especially the peasants would rise above that tribalism pressed on them by colonial rule and make possible the building of a new society (DAVIDSON, 1972, p. 316-317).

Claude Gabriel is a Trotskyite and sees the Angolan conflict as a class struggle between the masses and nationalist leadership. Although the MPLA comprised the left forces and the masses, after independence the bureaucratic bourgeoisie in power achieved advantage in that struggle against the masses, especially after the 1977 attempted coup, benefiting from the demobilization of the proletariat and the continued integration of Angola in the world-system (GABRIEL, 1978, p. 11-12).

Fola Soremekun admits that UNITA benefited from the sympathies of the Ovimbundu people, in the same way as the FNLA benefited from the sympathies of the Bakongo and the MPLA from the Mbundu, but only in the earlier years (SOREMEKUN, 1983, p. 7). For him, the subsequent conflict between the three parties was essentially based on political and ideological disputes, added to which was the pitiful nature of Portuguese colonization and the ineptitude of the Portuguese government during decolonization. It was "a struggle between what could be called the forces of 'genuine independence' for Angola [the MPLA] against those of 'neo-colonialism'” (SOREMEKUN, 1983, p. 212).

Michael Wolfers and Jane Bergerol argue that ethnicity was a phenomenon deliberately fostered by colonial authorities (WOLFERS; BERGEROL, 1983, p. 140) and that after 1974, the conflict was fired not by popular support (which they claim only the MPLA had before 1974), but by the counter-revolution created by 
the forces of imperialism (USA, Portugal, Britain, and France), involved with FNLA and UNITA against the MPLA (WOLFERS; BERGEROL, 1983, p. 4). "Yet MPLA defeated the imperialist military intervention." (WOLFERS; BERGEROL, 1983, p. 8).

Keith Somerville sees the ethnic divisions as being on pair with other social divisions that usually characterize rural and urban dichotomy, created by colonization; he argues that although ethnic identities had a profound impact on the construction of nationalist movements, the MPLA was the one who made a real effort to overcome ethnic barriers and acquire a national dimension. It was the only one of the three movements that, during and after the anti-colonial struggle, pursued true national politics, rather than the ethnic and regional politics characteristic of the other two movements (SOMMERVILLE, 1986, p. 71-73). The remaining analysis is centred around the institutional and typological aspects of the post-independence State in Angola, and the legitimating discourses of the MPLA government; he believed in the MPLA's sincere commitment to the construction of Socialism and its ability to change society even against South African destabilization (SOMMERVILLE, 1986, p. 13). There remained the need to adapt Marxism-Leninism to the country's specific circumstances (SOMMERVILLE, 1986, p. 196).

The third line of analysis attempted a more encompassing approach than the previous two. Authors within this line will attempt to escape, with different degrees of success, the simple division between ethnic and class/politicalideological interpretations. They complementary resorted to explanations based on socio-cultural specificities due to colonialism, the existence of dependency structures between urban centres and peripheral rural societies, international influences like the 'Cold war' and apartheid. Nevertheless, they did not question the characterization that was emerging from the previous discussions on the leftist-Socialist dominant orientation of the MPLA and ended up reinforcing such characterization. This category includes authors such as Franz Heimer, Gervase Clarence-Smith, David Birmingham, and Christine Messiant.

Franz Heimer tried to articulate class and ethnicity as explanatory variables within neo-marxist dependency theories. The Angolan nationalist division and the conflict between the movements was seen as a complex struggle between two 
camps or models of decolonization - between capitalist and non-capitalist options. The rationale behind the behaviour of the MPLA was characterized as predominantly ideological, leftist-Socialist. Nevertheless, deep, and partly crosscutting social cleavages, brought about by the kind of social formation created during colonialism, assigned clearly defined constituencies to each nationalist movement (MPLA included), thus rendering impossible a consensual political solution among the three (HEIMER, 1979, 1980).

On the one hand, the kind of social formation that emerged during colonialism is explained by Heimer in terms of a structure of central capitalist societies and peripheral, or tributary, pre-capitalist societies, in the style of the classic perspective of dependency theories: metropolis and satellites; dominating bourgeoisie and dependent rural peripheral societies (HEIMER, 1979, ch.1). On the other hand, when considering his many years of field research in Angola, the author acknowledged the poor development of class consciousness amongst the workers and the tendency of the ethnic component of identity to remain strong, especially in peripheral societies - about $80 \%$ at that time - that were less affected by class formation (HEIMER, 1972).

Articulating ethnicity and class, Heimer argued that within the existing social formations, social identity was made of several components determining several cleavages, namely, ethnic, racial, cultural and class. Such components or dimensions of social identity were alternatives that each individual resorted to, according to specific circumstances (HEIMER, 1979, p. 61-65).

With the 'electoral campaign' before independence and the conflicts between the three movements, a combination of those components started to delineate a pattern that had been foreseeable since the end of 1974, by which the possible outcome of elections to be held in 1975 "was thus almost exclusively a function of the relative demographic weight of the different population segments [...]." (HEIMER, 1979, p. 64).

In the end, although with a much more elaborate interpretation, Heimer was unable to escape the ethnic argument as the main explanatory variable. In fact, several years later, Marcum interpretation of the 1992 electoral results in 
Angola (based on his previous ethno-regional argument in support for political alignments) would come near Heimer's (MARCUM, 1993).

Gervase Clarence-Smith also resorts to a dependency theory interpretation but clearly rejected any relevance of the ethnic dimension of the conflict, claiming that underneath an appearance of ethnicity, the Angolan conflict has always concealed a class structure and a class struggle (CLARENCESMITH 1980, p. 109), and that all the liberation movements in Angola were conspiracies of class and regional interests that varied over time and had limited ethnic ideological appeal (CLARENCE-SMITH, 1980, p. 119). The impossibility of bringing about unity between the MPLA and the FNLA was due to the manœuvres of neighbouring States, and UNITA was the successful outcome of the FNLA's failed project in the 1960s for "a multi-ethnic alliance of Angola's peripheral rural societies" (CLARENCE-SMITH, 1980, p. 119-120).

Towards the end of the 1980s, this author did admit to the force of ethnic identities in Angola (which by then had effectively increased), but again explained that one of the paradoxes of the African situation was that class conflicts contributed to create social identities of an ethnic type, which was exactly the opposite of what "ordinary 'Marxists"' argued (referring specifically to Heimer) (CLARENCE-SMITH, 1989, p. 406-407). It was the formation of classes that led to the creation of ethnicity in Africa, whereby the least touched regions by the process of class formation were the least ethnic regions. He argued that contrary to what was usually sustained - that tribalism was invented by the elites to grab and maintain power -, ethnicity derived from class structures, and the reinforcement of ethnic identities was accompanied by the equal reinforcement of national sentiment in a dialetic relationship (CLARENCE-SMITH, 1989, p. 411412).

The author does not politically-ideologically characterize the project and discourse of the so-called UNITA's "multi-ethnic alliance of Angola's peripheral rural societies", as opposed to the MPLA's political project and leftist discourse of - we suppose - elitist regionalist peripheral urban societies. In his interpretation, a process of class formation (within a dependency theory with peripheral rural societies and peripheral urban societies), leads not to political- 
ideological discourse and dispute sedimentation, but to ethnicity and at the same time to a national sentiment without the support of any genuine domestic ideological project or discourse. Nevertheless, the MPLA was still originally characterized as leftist, although within an elitist perspective.

David Birmingham's analysis of the Angolan nationalist division in three movements and their inability to form a single movement, also stresses social cleavages articulated around several social identity dimensions (close to Heimer's argument) such as historical, cultural, ethno-linguistic, racial, religious, regional, sub-regional, urban/rural and socio-economic. Such cleavages resulted mainly from the nature of Portuguese colonization, based on three poles of opportunity, differing from the conventional colonial States, where the political, social, and economic life focussed on a single capital city. "It was therefore no accident that Angola [...] developed three political movements with three urban focal points, three missionary traditions, three vernacular languages and three rival sets of sub-national leaders." (BIRMINGHAM, 1988a, p. 1).

According to the author, the roots of the Angolan "civil" war were in part ideological, as the Portuguese deliberately encouraged the growth of a black capitalist peasantry in the coffee industry, where black provincial entrepreneurs, predominately members of the Baptist Churches, were supporters of the rightwing FNLA rather than the left-wing, city oriented MPLA. The author's interpretation of the Angolan conflict after independence was presented according to the tension between town and country paralleled by an ideological tension between right and left, between entrepreneurial and bureaucratic. The town, bureaucracy and the left were being represented by the MPLA, while the country, the entrepreneurial and the right were being represented by UNITA, though at the beginning of the conflict, they were represented by the FNLA (BIRMINGHAM, 1988a, 1988b). The whole political and military conflict in independent Angola until 1991 was read in these terms (BIRMINGHAM, 1992, p. 114-115).

Christine Messiant developed much further the previous argument of Birmingham on social cleavages resulting from a peculiar type of colonization and reflecting several of the socio-cultural identification dimensions stressed by 
Heimer and Birmingham (socio-economic, race, religion, region, sub-region, ethno-linguistic, historical, cultural, urban/rural). The author centres her analysis at the level of the elites or elite' fractions who could be identified in colonial history, especially towards the end of the nineteenth century and during the first half of the twentieth (CAHEN; MESSIANT, 1989; MESSIANT, 1983; MESSIANT, 1989). Such analysis provides an explanation for the Angolan nationalist division and the ensuing conflict between movements.

Insofar as Messiant will influence most of the sociological-politicalhistorical studies on Angola until today and is still the major reference for contemporary Angolan studies, we shall detail a bit more her reasoning and explanation.

The author claims that the nationalist movement in Angola was formed in the 1950s within a polarized framework, around two geographically separated elites - 'ancient assimilados' and 'Bakongo évolués' -, to which a third one was later added - the 'new assimilados' (MESSIANT, 1983, 1989, 1994, 1995a).

The ancient assimilados came from the multiracial colonial bourgeoisie that existed until the twentieth century, comprising mainly mulattos but also including blacks, sidding with the whites in the structures of colonial society until the twentieth century, adopting the Portuguese language and the catholic religion. Emerging politically in urban centres of Europe and Angola, because of their privileged status as educated elites, these militants denounced the racial domination of colonization and the failure of assimilation; they adopted nationalism supported by values that were creole, universalistic, national, multiracial, Christian humanistic but also Socialist. It is from this group that emerged those who were to form the MPLA, who were to give it its shape, its discourse, and its ideology. ${ }^{2}$

The 'Bakongo évolués' emerged from the numerous Bakongo emigrants to the Belgian Congo, especially in Léopoldville, where the elites were known as évolués. Following the example of the Congolese elites, this particular Angolan elite challenged colonialism, exalting the black race and the Congo people's pride.

\footnotetext{
2 Also extremely elucidating on this subject and in this sense, see major reference works in Portuguese from Marcelo Bittencourt (BITTENCOURT, 1999, 2008) and Jill Dias (DIAS, 1984).
} 
They were the founders of UPNA (Union of the People's of North Angola), then UPA (Union of People's of Angola), then political movements that gave rise to the National Liberation Front of Angola - FNLA, which was first of all an ethnonationalist movement, whose leaders belonged to protestant families and the aristocracy of the kingdom of the Congo. Their ideology was liberal-nationalistic, but radically African, being very much opposed to any Portuguese cultural influence.

Towards the end of the 1950s and the beginning of the 1960s, there was an extreme contrast between these two elites; both sides mutually and strongly rejected each other.

As for the 'new assimilados', they did not issue from the old colonial bourgeoisie, but from indigenous African society. They were assimilated only in the twentieth century and in growing numbers after World War II, thanks to the missionary education they received in indigenous milieux (mainly protestant and foreigner, non-Portuguese). However, assimilation did not open for them the doors to social promotion because of the rigidity of racial stratification derived from white immigration, and because of the stronger competition of the 'old assimilados', most of whom were Catholic.

Faced with two camps polarized between the MPLA and the FNLA, the 'new assimilados' joined one or other of the two camps, according to the specific fracture lines of their religious, ethnic or regional group. Historically specific ties between new and old assimilados in the old centres of colonization (i.e., Luanda and its hinterland and the small area of Lobito-Benguela) favoured their alliance within the MPLA. These historically specific ties made the alliance of blacks and mestizos, Catholics and Protestants, ideologically committed and nonideologically committed, a lot easier.

Out of the old centres of colonization there is an alliance of the other new assimilados ('Ovimbundu' from the congregationalist missions and 'Bakongo' from the baptist missions) with the 'Bakongo evolués' within the UPA/FNLA. Finally, there is the three-way division of Angolan nationalism in the mid-sixties after the departure of Savimbi and his followers from the UPA/FNLA - accusing 
the movement of favouring the "Bakongo's , but still finding the MPLA too Creole, assimilated and mestizo to be joined by them - forming instead their own movement -- UNITA (BRIDGELAND, 1986; MARCUM, 1978).

In sum, according to Messiant, the division of Angolan nationalism in three movements is the result of a competition between rival elites for power; a rivalry firstly exercised during the anti-colonial struggle and founded on socio-cultural cleavages (elite fractions, race, religion, region, ethno-linguistic) resulting from an unequal historical and geographic development of Portuguese colonization in Angola.

As for ideology, Messiant explains that the dynamics of a civil war massively involving the population (with strong instrumental use of social and cultural differences by the elites to legitimize their autonomous - i.e. exclusive existence) and the 'cold war' alignments - also instrumentalised by the nationalist movements ${ }^{4}$-, contributed to a strong exacerbation and politicization of the differences between peoples, hardening the opposition between movements, giving another dimension to the conflict, not only in terms of ethnicity, but also in terms of ideological alignment (MESSIANT, 1994, 1995a, 1995b).

As we can see, Messiant's work is the most developed within the third line of analysis and was the one that successfully articulated domestic and international dynamics within a sociological-historical perspective, coherently articulating socio-identity cleavages, class analysis with and ideology. Nevertheless, as the relevant point for our paper, the author still sustains a deepening ideological character to the conflict, that leads us to eventually assume the dominance of the ideologically committed sector within the MPLA after the independence, which was absolutely not the case.

As becomes clear from the presented influential discussions, no matter how, or on what level and degree of intensity the ideological factor was integrated

\footnotetext{
3 See 'Letter to the Missionaries of the United Church Board for World Ministries in New York,' dated 21 September 1966, cited in MARCUM 1978, p.165-166.

${ }^{4}$ For the argument on the domestic internationalizationof the Cold War see also GUIMARÃES 1998, p. 199)
} 
and assimilated, all these analyses contributed to the international dominant generic characterization wherein the MPLA was increasingly identified as Socialist, left, Marxist, progressist, while the FNLA and UNITA were increasingly characterized as nationalist ethno-regional rural-traditional rightist.

The sedimentation of political-ideological characterizations emerging from these discussions within a context of civil war and global Cold War alignments, hampered a more objective analysis unable to denounce the fake Socialism of the MPLA, as shown in part II of this paper. As a matter of fact, the non indeologically-committed wing of the MPLA, won the struggle. In the most stinkingly way, during the administration of the first President of the Republic and President of the MPLA - the founding period of the so-called MPLA MarxistLeninist Socialist party - the party was able to effectively proceed with a rightwing (liberal) policy, while retaining the unquestioned international SocialistMarxist epithet. ${ }^{5}$

\section{II - The liberal right-wing governing practice of the MPLA in contrast with a Socialist discourse and designation}

Despite the already internationally dominant epithet of Socialist, at the independence of Angola in November 1975, the MPLA was still far from adhering to Socialism. As late as August 1975, although pretty much unnoticedly, Agostinho Neto was stating that,

The MPLA is not a Marxist-Leninist organisation. Nor is our leadership Marxist-Leninist. [...] We are a large organisation with various shades of opinion and different types of groups. [...] As a heterogeneous organisation, it contains both Marxist and other points of view. (AGOSTINHO NETO, 1975) ${ }^{6}$

\footnotetext{
5 Although this paper deals with the MPLA, for reasons having to do with the fact that it was the movement that came to effectively govern the State and whose policies can be easier followed and scruntinized, the same argument could probably be used to the FNLA or UNITA. These movements had a parcourse that also challenged and oftenly contradicted the dominantly attributed characterization.

${ }^{6}$ Such statement was originally published in Afriscope, August 1975, and reproduced in Africa Contemporary Record - ACR, 8, 1976, p.B423, which was in its turn used in this paper.
} 
Equally, the first version of the Constitution (11 November 1975) does not have any reference to the construction of Socialism either. ${ }^{7}$

In general, nationalist movements were large and ecletic sociologicalpolitical fronts, aggregating people from a varied sociological-historical-political, ethno-linguistic and regional background, with anti-colonialism emerging as a minimum common denominator, but concealing different expectations and opposing views and projects for the future independent State (BITTENCOURT, 1999, 2008; MABEKO-TALI, 1996²).

The Angolan case was even more so, with an initial bi-partite nationalist struggle (MPLA and FNLA) and then tripartite (UNITA), unable to form a united front againt colonialism. Moreover, as we could see through the socio-politicalhistorical analysis of some of the authors presented in part I, there were several cleavages inside the movements themselves, and especially inside the MPLA, that effectively came to hegemonically assume the new State.

In fact, and despite the domestic and internationally dominant designation of Socialist, the MPLA was still undergoing a process of definition in terms of its political project for the new State. Some of the historical cleavages of elite segments inside the MPLA, will politically crystalyze at independence and polarize in top leadership organs such as the Political Bureau and the Central Committee.

However, as concluded in part I and according to the argument of this paper, it would still be misleading to keep on with a sterile discussion centered on the ideological cleavages of specific elements within the top organs of the MPLA prior and during the independence (Troskyites, pro-Chinese, pro-Soviet, Guevarists, Albania-ists, Tito-ists and so on) or even to insist in the usual politicalparty models of analysis, according to which the MPLA institutionalized as a mass party organization.

This is not to say that such individuals and discussions did not exist or were irrelevant by then, or even less to say that there were not ideologically sincere and committed individuals inside the top organs of the MPLA. This is to

\footnotetext{
7 See Constitutional Law, Diary of the Republic, Ist series, nำ1, 11 th November 1975.

8 Two editions based on this thesis were published in Portuguese, one in Angola and one in Portugal, but I will stick here to the original version in French.
} 
say that such discussions, besides the fact that were essentially limited to a slice minority of an elite segment (urban, young, educated), soon eroded, and vanished, as other more objective and decisive issues came to the fore and specific governing decisions had to be made. Moreover, this is not to say that the MPLA did not officially assumed the figurine of an intended mass party organization. This to say that above and beyond such realities, the political system soon evolved to become increasingly Presidentialist, elitist and personalized, concentrating ever-growing powers in the hands of the President of the Party, President of the Republic, Chief of Government, Higher Magistrate of the Nation and Commander-in-Chief of the armed forces - all embodied by Neto, who effectively realised the need to unashamedly assume a personalization of power, especially after the attempted coup of May $1977 .{ }^{9}$ In face of such reality a new analytical perspective should be followed to avoid the referred analytical pitfalls.

The argument here is to propose a different analytical perspective to objectively assess the effective political orientation according to the analysis of the effective political practice beyond the ideological discourses and politicalparty models. In order to do that we would resort instead to the old, but certainly more useful and accurate, characterization of "left" and "right" provided by Immanuel Wallerstein to analyse the post-independence African political systems according to very specific criteria: 1) decision on political economy; 2) decision on political management and the place of ideology in it; 3) decision on foreign policy (WALLERSTEIN, 1971).

In these terms and according to these criteria, we will observe the top leadership polarization of the MPLA in two radically opposed perspectives for the new State. Although the conflict between these two perspectives could be sensed in several political speeches and conflicts inside the nationalist movement (before independence), it only blossomed after independence, as soon as the MPLA assumed the independent State and effectively started to govern.

\footnotetext{
${ }^{9}$ I will not enter the analysis of that process of presidential power concentration and party elitism as it was addressed in VIDAL 2007.
} 
At the start of Agostinho Neto's administration of the new independent State in November 1975, the MPLA's top leadership was more-or-less stable from previous political disputes, having defeated previous internal threats to Neto's power, such as the Active Revolt and the Eastern Revolt at the Moxico Inter Regional Conference of Militants in September 1974, which confirmed Neto as President. ${ }^{10}$

It is within a relatively stable period of leadership, dominated by staunch supporters of Agostinho Neto, that the two perspectives - here called left and right wings - began to grow, vying for influence near Neto and trying to set the pace on the future political-economic and foreign policy orientation of the country.

Before entering a brief sociological-political characterization of these two wings, it is important to stress that their confrontation started right at the start of this relatively stable period with a first advantage to the rightwing soon after the independence. Their influence over Neto was significant and became to be ironically referred within the leadership as Catetização do Poder - Catetization of Power, referring to the regional origin of most of the members of that group Catete -, which was also the place of origin of Agostinho Neto (MABEKO-TALI, 1996, p. 411). Such confrontation was soon suspended in face of the rising threat that led to the attempted coup of May 1977, and then again re-ignited as soon as that threat disappeared. Their existence is therefore prior to the attempted coup and to the political movement that led to the attempted coup.

\section{The left-wing}

On the one hand, there was a group mainly comprising mestizos, clearly related to the coastal non-protestant new assimilados/creoles, heirs of the colonial bourgeoisie of the beginning of the century (not to be confused with the old coastal aristocracy segment of the 'old assimilados/creoles').11 They assumed

\footnotetext{
10 For a detailed characterization of those previous political disputes that are necessarily out of the scope of this paper, see BITTENCOURT 2008, vol. II, p. 238-250.

${ }^{11}$ I will not enter here the long and still open discussion on creoles and assimilados, for such a discussion see for instance: MESSIANT 2006; BIRMINGHAM 1981, p. 1-14; BIRMINGHAM 2015; BITTENCOURT 1999, ch. V.
} 
an ideological Marxist stance and their most prominent members were Carlos Rocha Dilolwa, minister of economic planning, Lúcio Lara, member of the Political Bureau, Iko Carreira, minister of defence, António Jacinto, writer, and Paulo Teixeira Jorge, foreign minister.

In terms of economic policy, the left-wing group stood for an all-out fight against the anti-revolutionary practices as had been evolving since independence, which included the black market, absenteeism, diversion of produce, and nonfulfilment of production targets (LAW..., 1975). ${ }^{12}$ They also supported a deeper economic co-operation with countries of the Eastern bloc, especially Cuba. This left-wing position on economic principles was led by Carlos Dilolwa (minister of planning and second deputy prime minister).

In terms of political management, the left argued for a system exclusively determined by revolutionary-ideological criteria, whereby the top (strategic) positions of the party and the State should be occupied by a vanguard, properly versed, and committed to, Marxism-Leninism; rejecting any criterion of ethnoregional demographic weight, therefore rejecting the right-wing pressures for a black M'Bundu base of power, which they saw as tribalistic. Although respecting the possible ideological honesty of such position, we cannot ignore that it served well the interests of its proponents (VIDAL, 2016, p. 826-827); despite the smaller demographic weight of this lighter skinned segment of elite, their relatively higher educational level and ideological preparation would ensure their political primacy in a vanguard party.

In terms of foreign policy, they sustained an intransigent path alongside other Socialist countries, reinforcing the Cuban presence at all levels of cooperation (military and civil), rejecting any concession towards the US/South Africa demands for Cuban troops withdrawal and rejecting a relationship between the presence of Cuban troops in Angola and the independence of Namibia (UN 435 resolution). ${ }^{13}$ Likewise, they rejected any negotiation with Mobutu's Zaire, a long time and declared enemy of Neto's MPLA and US ally. At

\footnotetext{
12 For a detailed description and denounce of such practices, see 'Law for the Disciplining of the Productive Process', Law 11/75, Diário da República, I, 29, 15

${ }^{13}$ On the linkage between Namibia independence and the withdrawal of Cuban troops see WRIGHT, 1997.
} 
this level, the most prominent member of the left-wing standing for these positions was Paulo Teixeira Jorge, foreign minister.

\section{The right-wing}

On the other hand, there was a group mainly comprising the darker skinned, protestants, 'new creoles' from the interior (mainly from Catete, the birthplace of Agostinho Neto), including some of the survivors of the nationalist insurrection of 1961 and/or the first generation of political prisoners and nationalists of the late fifties. Their most prominent members were Agostinho Mendes de Carvalho - 'Uanhenga Xitu', Domingos Paiva da Silva, Imperial Santana, Bernardo de Souza, and Manuel Pedro Pacavira. Their education level was in average lower than the leftists, whom they saw with resentment as 'intellectuals', and their political stance had nothing to do with Marxism, standing for what can be considered as tradition and ethnicity, defending a M'Bundu (black) base of power with a dominance of the M'Bundu from Catete (MABEKO-TALI, 1996, p. 411). ${ }^{14}$

In terms of economic policy, the right-wing sustained a more pragmatic and 'liberal'-flexible position, accepting socio-economic organisation as it now was - officially condemning, but pragmatically accepting the economic schemes that had meanwhile evolved, which in fact represented a generalised straddling between legal and illegal markets (private business) through a hierarchical/discriminatory distributive system of benefits and privileges managed by the top leadership of the Party (VIDAL, 2011). They had little faith in the communist policies of collectivisation of the land and of other economic assets and criticised the left-wing radical stance towards the private initiative (VIDAL, 2016, p. 820-821).

In terms of political management, the right-wing supported a leadership system based on culture and tradition, respecting the demographic weight of each Creole/M'Bundu elite segment within the MPLA, through which, though less

\footnotetext{
14 Two editions based on this thesis were published in Portuguese, one in Angola and one in Portugal, but I will stick here to the original version in French.
} 
ideologically and academically educated and from the interior of the country, they could achieve political primacy, dethroning the left-wing lighter skinned, coastal ideologues.

Once assured of their primacy within the Creole/M'Bundu core of the MPLA and following the same logic, they favoured a balanced (secondary) representation of other regional and ethnic sensibilities within the party ranks. Such logic should be extended to those groups outside the MPLA, attracting their members (cooptation) within the middle rank hierarchy of the party, thus broadening the socio-political support of the MPLA.

In terms of foreign policy, they placed nationalism above internationalism, having serious reservations about the Cuban presence, sustaining a more flexible and pragmatic approach towards the West and especially the US and South Africa, as well their major ally in the region - Mobutu's Zaire. They accepted the possibility of making concessions towards the US/South Africa demands for Cuban troops withdrawal to facilitate the implementation of UN resolution 435 and the US recognition of the Angolan government (VIDAL, 2016, p. 821).

The main common denominator between these two groups was their proximity to and support for Agostinho Neto, because he had links with both and provided a useful balance within the leadership. He was Protestant, but communist; he was black from Catete in the interior (but quite acculturated, being a medical doctor who had trained in Portugal and even married a white Portuguese) and had a long and strong friendship with many mestizos and the most prominent figures of the left wing, such as Lúcio Lara, Iko Carreira and Carlos Dilolwa.

\section{Neto and the struggle between the 'left' and the 'right' wings}

As said, a clear dispute between these two opposite wings started at independence, although by then was not as defined as characterized above. Such definition, in terms of organizational political standings, progressively emerged only after the new threat to Agostinho Neto's leadership was effectively crushed. 
That new threat started to grow in the first year of independence, through 1976, coming from a motley alliance of youth groups and former guerrilla from the Ist military region (Dembos), that ended up led by Nito Alves, culmminating in an attempted coup d'Etat in $27^{\text {th }}$ May 1977, defeated in extremis by the Cuban military.

As the new threat began to form, both party wings immediately left their divergences aside and formed a common front to defend Neto and themselves at the top of the apparatus. Within an intricate domestic and international context, that is out of the scope of this paper, that emerging threat was decisive to the official adherence to Marxist-Leninist Socialism at the third Central Committee meeting (23-29 October 1976). ${ }^{15}$

In the coup aftermath, a bloody purge resulted in thousands of deaths (PAWSON 2014) and the party went through a so-called rectification process to get rid of harmful elements (MPLA, 1977, p. 19). The I congress in December 1977 , consecrated the MPLA as a workers' vanguard party according to Marxist-Leninist principles (RELATÓRIO..., 1977, p. 17). A new constitution approved in February 1978, stated for the first time that the objective of the party was the construction of a Socialist Society. ${ }^{16}$

Such official ideological option would expectedly mean a settlement on the dispute between the left and right in favor of the left. However, that was not the case at all.

In a somehow contradictory way, as soon as the Nitista threat was crushed, the suspended struggle between left and right resumed and progressivey increased to reach its height at the CC's plenary in December 1978 (6 to 9 December). There the two wings pressured Neto to take sides. However, the president's hybrid nature and gratefulness to both sides, and his already strong personal/institutional control over the whole political system, allowed him options close to the ones sustained by the right-wing (which he effectively shared), but without making it look like a public defeat for the left. His standings

\footnotetext{
${ }^{15}$ For the public announcement of such adherence to Marxist-Leninist Socialism, see Africa Contemporary Record - ACR, Angola section, 9, 1978, B453.

${ }^{16}$ As stated in article 2 of the Constitutional Law, Diário da República, I, 31, 7th February 1978.
} 
in terms of political economy, political management/ideology and foreign policy, showed his ability to signal to the left while turning to the right, within the instrumentalization capacity to maintain the epithet of Socialist while in fact governing to the right.

\section{Economic policy}

In terms of economic policy, the left-wing suffered a major defeat. The pragmatism and 'liberalism' sustained by the right-wing won right out. Internally, the Central Committee plenary gave the go-ahead to private Angolan businessmen to set up construction companies and trucking businesses (merchandise transport to provinces). At a rally in Luanda on 10 December, the day after the meeting, Neto stressed that private Angolan capitalists would have a role to play in the country's economy (ANGOLA..., 1980, p. B487). Somehow trying to smooth down the previous statement, a few days later Neto explained that such a move did not mean that the aim of establishing a communist State was abandoned, but that the immediate and urgent need was just to get the society working smoothly and to solve the people's problems (AGOSTINHO NETO, 1978a).

A week later, on 17 December, Agostinho Neto declared "the need to offer more possibilities to private initiative in our country [...] which is not as counterrevolutionary as might seem at first." (MEYNS, 1984, p. 144). He also announced the lift of the prohibition towards informal construction (recognising the State's incapacity in the housing sector) and suggested a more flexible attitude towards the petit commerce as a possible way to help the recovery of rural markets, recognising that 'men and women who live in the country suffer a lot, because they can hardly sell, buy or even produce' (CONCHIGLIA, 1978, p. 23-25).

By then, even foreign observers sympathetic to left-wing positions such as David Ottaway, justified the need for Neto's pragmatism, noticing that "Every Luanda grocery store seems to have a long queue outside, and fruit, vegetables and meat are in short supply" (OTTAWAY, 1978). 
Nevertheless, such pragmatism was seen as a major setback to the leftwing, especially to Carlos Dilolwa, having immediately resigned his place in government (as second deputy-prime minister for economy) and his politburo seat. The prime minister Lopo do Nascimento, by then assuming a position close to Dilolwa, lost his place at the Politburo and his place as prime minister, a position that was quite simply abolished and powers transferred to the Presidency in a process of power concentration that accelerated (VIDAL, 2007, p.124-174).

A few months later, during his May-Day speech, Neto specified the new areas open to private initiative, comprising private commercial activities of food and consumer goods to help to make up for shortages caused by inefficient production and distribution (AGOSTINHO NETO, 1979c). At the same time as Neto was announcing several concessions towards the private sector, the MPLA's Politburo May Day official statement was more hypocrite than ever, increasingly resorting to Socialist jargon to mask the right-wing turn,

Some sectors of the petite bourgeoisie want to step into the shoes of the colonial bourgeoisie and thus increasingly assume the ideological and moral values of capitalism -- disdain for the working class, refusal to solve the concrete problems of the masses, the love of luxury and the easy life, the spirit of ostentation, negligence, political and economic corruption, opportunism, spreading of obscurantism and superstitious concepts -- in a word all the retrograde moral values of the enemy. (MPLA'S..., 1979)

Externally, Neto had already shown some signs of pragmatism and liberalism even before the CC plenary. Trying to normalise economic relationships with the West, the president began to approach the EEC countries in general and in July 1978, Claude Cheysson, the EEC's Commissioner for Development, visited Angola, and according to his own words,

Angola wanted to increase trade with the West and welcomed Western investment [...] I was struck by the desire of Neto and his Ministers to immediately discuss certain development problems. Their traditional partners cannot offer them much in this field (CHEYSSON, 1980, p. B497). 
Belgium foreign minister, Henri Simonet, was told by Neto that Angola was eager to establish co-operative economic relations with West European countries to diversify its international relations and reduce its dependence on Cuba and the Soviet bloc (SIMONET, 1978a). Neto showed his interest in private Western investment on a large scale, mainly directed to oil exploration (besides Gulf and Petrofina), but also including development projects in other areas such as fisheries, the recovery of the port of Lobito, the Benguela Railway, iron, and uranium mines (AGOSTINHO NETO, 1978a). In the meantime, Angola was granted the status of observer in the renegotiations of the Lomé Convention. ${ }^{17}$

At the level of foreign economic policy, a few days before the plenary, Western reporters already talked of a shift from ideology to pragmatism as the 'economy founders' (LAMB 1978a; LAMB 1978b; OTTAWAY 1978). By the time of the CC plenary (6-9 December 1978) the economic approach towards the West was re-affirmed and made concrete. Neto, thus announced the preparation of a new and more attractive law for private foreign investment, which was effectively passed in July 1979, covering all aspects of economic activity, allowing several benefits such as the repatriation of profits, guarantees of compensation in the event of nationalisation, exemption from tax and from customs duties (PEEL 1979; HODGES 1987). ${ }^{18}$ In the specific case of the oil sector, the new law was even more 'liberal' than the ones already approved in 1978 (BHAGAVAN, 1980, p. 21).

\section{Political management}

After the plenary Neto put in place a management system based upon the distribution of privileges and benefits through rotating nominations to party and State top positions; making for a kind of a carrousel of posts on which the key elements of the party rotated according to the political needs of a system which considered ethno-regional balances (ethnic, sub-ethnic, regional, and racial). This balance was in fact meant to be skewed in favour of the Creole/M'Bundu core of the MPLA. Such supremacy was achieved not only through the party's all-

\footnotetext{
17 The renegotiations of the Lomé Convention took place in Brussels, on 18 September, in a joint session between the EEC and ACP countries (African, Caribbean and Pacific); reported at

"Angola section" at Africa Contemporary Record - ACR, 11, 1980, p.B497.

18 For the specificities of such legislation, see HODGES, 1987, p.32-33
} 
powerful presidency, but also through the occupation of a higher number of top positions - mainly in the politburo, the Central Committee, the General Staff, central and local government (ministers, vice-ministers, secretaries of State and provincial commissioners), top management of public companies and embassies abroad (VIDAL, 2007).

In these terms, after the plenary the president remodelled the top organs of the party and of the State, starting with the politburo, which was to comprise three mestizos (Lúcio Lara, Iko Carreira and António dos Santos França 'N'Dalu'), three black Mbundu (Agostinho Neto, Eduardo dos Santos and João Luís Neto 'Xietu'), three Bakongo (Pascoal Luvualo, Rodrigues João Lopes 'Ludy Kissassunda' and Ambroise Lukoki) and two Cabindan (Evaristo Domingos 'Kimba' and Pedro Maria Tonha 'Pedale'). ${ }^{19}$ With six elements, the supremacy of the Creole/M'Bundu was assured.

The Ovimbundu were the only major ethnic group not represented in the politburo because of the resentment provoked by renewed UNITA/South Africa offensives and closer identification between the Ovimbundu and UNITA. Below the politburo level, some MPLA Ovimbundu old time members managed to achieve top positions, such as Faustino Muteka, appointed minister of transport in January 1979. ${ }^{20}$ Following the same management principles of rotation and micro-identity balance, there was reshuffling in the CC and in the central and provincial governments; in 1979, all provincial commissioners were ex-officio members of the government. ${ }^{21}$

Beyond those very top organs, at an intermediate level of the State hierarchy, a few months before the plenary Neto had already shown signs of wanting to manage the political system based on the strategic or selective cooptation of members of other movements and even of MPLA's dissident groups. Therefore, in September 1978, he announced in Cabinda, his policy of

\footnotetext{
19 The secessionist tendencies, the activities of FLEC and the growing economic dependency from oil demanded special attention to Cabindans, reserving them important places at the top organs of the Party.

${ }^{20}$ As announced at Rádio Nacional de Angola broadcast of $17^{\text {th }}$ January 1978 , cit. in Survey of World Broadcast, 1979.

${ }^{21}$ For a complete outline of such extensive reshuffling see Diário da República, Ist series, November-December 1978, esp. ㄲo266 to №301, and January-December 1979.
} 
clemency and partial amnesty followed by integration, towards members of the FNLA, the FLEC (Liberation Front of Cabinda's enclave), the 'Active Revolt', the 'Eastern Revolt' and Nito's sympathisers, but still without mentioning UNITA (AGOSTINHO NETO, 1979a, p. 43-54). As a result of this new policy of clemency, several top members of the FNLA deserted and surrendered to the MPLA during 1979, after which they were reintegrated within State structures, along with the freed members of MPLA's previous dissident groups ('active revolt' and 'Eastern revolt'). This re-integration/cooptation strategy was pursued in parallel and articulation to an also pragmatic/realistic foreign policy as follows.

\section{Foreign policy}

Along with the attempted normalisation of economic relationships with the West (during the summer of 1978), Neto also pursued a foreign policy designed to weaken the external support for the opposing movements still fighting the MPLA government - what was left of FNLA, and FLEC, and even UNITA.

Ignoring the opposition of the left-wing at the Politburo, Neto approached the long-time MPLA's enemy - Mobutu's Zaire -, re-establishing diplomatic relations in July 1978 and officially visiting Kinshasa in the following month; Mobutu also visited Angola in October. After the meetings, Neto got Mobutu to announce the expulsion of the FNLA and the FLEC from Zaire and on 27 October 1979, Holden Roberto was expelled from Zaire, taking refuge in Paris with several other leaders of the movement, while others surrendered through the referred policy of clemency.

At the international level (West), Neto approached not only the EEC countries as referred, but also Portugal, where UNITA found support among the Angolan refugees in Portugal and Portuguese returnees. In June 1978, a meeting between Neto and Portugal's President Ramalho Eanes in Guinea-Bissau, resolved many of the issues negatively affecting the Angolan-Portuguese relations since independence, such as the activities of the FNLA, UNITA and FLEC in Portugal. ${ }^{22}$

\footnotetext{
22 As reported at the Angola section, Africa Contemporary Record - ACR, 1980, p. B496-B497.
} 
Neto went even further, approaching the US, expressing the availability to discuss a possible reduction of dependency on Cuban and Soviet influence, as long demanded by the US. On the US side the move was reciprocated and the Secretary of State, Cyrus Vance, announced in June 1978 that Washington "wished to improve its relations with Luanda" (VANCE, 1978). Right after the CC plenary, a US delegation visited Angola on 13 December and was told by Neto that Angola was "prepared and willing to establish diplomatic relations with the US, although it could do nothing about reducing the number of Cuban troops because of South Africa's daily attacks" (OTTAWAY, 1978; LEWIS, 1978). By then, despite the Cuban military presence, Washington came very close to recognise the Angolan government (WRIGHT, 1997; PATRÍCIO, 1997). The sudden and unexpected death of Agostinho Neto in Moscow during a cancer operation on 10 September 1979 and the election of a republican administration, overtly supporting UNITA, reversed the diplomatic progress.

Despite such clear and ful speed advancement on right-wing liberal policies and orientation, the party's official discourse was more Socialist than ever, full of cosmetic revolutionary jargon in official documents. In terms of specific individuals, the internal balance between the two groups was in general maintained. With the exception of Carlos Dilolwa, who in fact resigned from his functions at the politburo and the government, the left-wing members in general kept their seats within the CC and the Politburo, as the right-wingers kept theirs at the $\mathrm{CC}^{23}$

\section{The real economy for the common people}

For the gross majority of the population, the pragmatic economic positions assumed at the top of the system were obviously seen as an unofficial acceptance to the private/informal/illegal procedures that had been rife in all sectors of activity and throughout all social strata. Contrary to Neto's announced provisional character for such concessions to private initiative, it became clear to everybody that it was an irreversible path and would only but increase.

\footnotetext{
${ }^{23}$ Left-wingers as Lúcio Lara and Iko Carreira remained in Politburo and Lopo do Nascimento lost his place at the politburo but not at the CC; right-wingers as Mendes de Carvalho, Domingos Paiva da Silva, Bernardo de Souza and Manuel Pedro Pacavira remained at the CC.
} 
[In early 1980] 'Despise the private' so characteristic of the first years of independence, was progressively transformed in 'desire to be private' [...] Those in 1976 who attacked the saboteurs of the economy [the ones in the informal/private sector] were now beginning their path towards 'entrepreneurship', having gone through the intermediate and uncomfortable phase of candongueiro [person acting in the black market]. (ZENHA-RELA, 1992, p. 57-58).

In the same terms, the ethno-regional solidarities assumed at the top organs, soon spread. The 1980 congress documents (majorly influenced by the left), which denounced all the previously referred informal activities - generalised thefts, diversion of produce, corruption, organised networks, involvement of managers, cadres and security forces, and so on -, also attacked the prevailing solidarities making it possible, namely the 'regionalism, racism and sectarianism [...] which contributes to the disorganisation and indiscipline in production and distribution, hampering the progress [...] towards Socialism.' (Resoluções e Mensagens do 10 Congresso Extraordinário do MPLA-PT, 1980, p. 36).

The CC report went even further, stating that,

The divisionist elements who take advantage of still-existing prejudice, be it tribal, regional or racial, within Angolan society, just so they can pretend to be 'defenders of the people' whilst striving for personal interests or those of their group, must be persecuted as enemies of the working class, of the Angolan nation and of Socialism [...] Regionalism, tribalism and racism are reflections of pre-capitalist production relationships and colonial domination (RELATÓRIO..., 1980, p. 37).

A third congress document, drawing an economic and social balance of the 1978-1980 period added to those prevailing solidarities the 'nepotism' and apadrinhamento [Godfather protection], thus 'promoting incompetence'. (PRINCIPAIS..., 1980, p. 11-27)

What made ethnicity, regionalism, or nepotism 'a problem' in Angola as elsewhere, were the inherent socio-economic distortions it generated (BAYART, 1989, ch.1). Such distortions could be effectively felt in Angola's daily life, as a national phenomenon spread throughout the whole country, as stressed by Neto in 1978, 
We know that there is tribalism still. It exists and we can feel it here in Bié [central plateau], in Luanda [centre-North], in Zaire [North], and in the provinces of Cabinda [North enclave] and Moxico [East and South-East]. It is there, despite the work we have been undertaking in order to accomplish national unity. (AGOSTINHO NETO, 1979b) ${ }^{24}$

The principles of political management adopted by the president at the top of the system in favour of a more 'balanced' ethnic and regional composition of top organs ended up as an 'official' acknowledgement of the necessity to politically manage such reality, thus integrating it instead of fighting it as officially declared.

By the time of his death in September 1979, Neto had set the dispute on political-economic orientation, which clearly consecrated a pragmatic right-wing path, under the formal and official cover of a Marxist-Leninist Workers' Party (MPL-PT).

Meanwhile, as the civil war raged high, within the global Cold War framework, so has the epithet of Socialist to politically-academically characterize the MPLA regime, domestically and internatonally. However, as we saw, that was far from being accurate. Despite the official inflammatory socialist discourse, the governing policies effectively turned right in terms of economic orientation, political management, and foreign policy, which are the ones that basically characterize the political-ideological orientation.

\section{Conclusion}

As shown in this paper, the domestic and international characterization of the MPLA as a Socialist, Marxist, leftist movement/party, was in great part a creative illusory process that did not objectively reflect the governing practice.

The MPLA leadership before independence was for a certain period strongly influenced by a specific sub-section of the elite, so-called intelligentsia or intellectuals, most of them heirs of the so-called Creole/Mbundu elite (old

\footnotetext{
${ }^{24}$ As broadcasted by Rádio Luanda on $12^{\text {th }}$ February 1978, cited in Africa Contemporary Record (ACR 1979, p. B505). Later, in December 1978, Neto referred again such problems of 'racism, tribalism and regionalism', as broadcasted by Radio Luanda on $17^{\text {th }}$ December 1978, cited in survey of World Broadcast, Angola, 1978.
} 
assimilados), studying in Europe, proximate and more or less well-versed on socalled leftist, progressist, marxist literature, authors and ideology. That was most clearly the case of its main strategist and one of the MPLA founders - Viriato da Cruz - who left the movement in disagreement with Agostinho Neto in 1962 (LABAN, 2003; ROCHA et al., 2008). Such initial segment of MPLA's members and their positions might somehow have given the initial support to the process of domestic and international academic-political characterization of the MPLA as a Socialist movement/party. However, that was not an accurate analysis, insofar as the movement itself never assumed officially as such until October 1976 and soon proceeded within an apparent contradiction wherein right-wing liberal nationalist policies were increasingly followed in parallel to an accentuated official Socialist discourse. A non-Socialist commited sector of the movement/party, here called right-wing, prevailed around Agostinho Neto (himself sustaining and leading such orientation) and managed to disguise a rightturn (liberal-nationalist) with a leftist innocuous Socialist jargon for cosmetic camouflage.

That characterization grew stronger and unquestioned throughout the 1970s and 1980s, partly sustained by foreign characterization (political-academic), partly supported by the civil war alignments within the global Cold War framework, as well as by the official discourse of the MPLA leadership itself, which politically instrumentalised such characterization, whitin a fake Socialism that proceeded unscrutinized on more accurate and objective analytical basis.

In the end, although Viriato da Cruz left the movement within a crisis mostly related to racial/ethnic issues above ideological ones, his alleged ideological concern, expressed by then, seems to have materialized, that Neto's leadership could in time represent a right-turn (MENEZES, 2017, p. 150, footnote 22). 


\section{References}

'LAW FOR THE DISCIPLINING OF THE PRODUCTIVE PROCESS': LaW 11/75. Diário da República, Luanda, Ist series, 29, p. 2-4, 15 Dec. 1975.

AGOSTINHO NETO. Seleç̧ão de discursos do Camarada Presidente Agostinho Neto. Luanda: Publicações MPLA, 1979a.

AGOSTINHO NETO. Rádio Luanda on $12^{\text {th }}$ February 1978. Africa Contemporary Record - ACR, London, v. 10, p. B323, 1979b. Angola section.

AgOSTINHO NETO. Associated Press, New York, p. 39, 2 May 1979c.

AGOSTINHO NETO. West Africa, London, p. 25, 23 Oct. 1978.

AGOSTINHO NETO. Statements produced in August 1975. Africa Contemporary Record - ACR, London, p. B423, 1976. Angola section.

AGOSTINHO NETO. The New York Times, New York, p. 14, 18 Sept. 1978a.

[ANGOLA SECTION]. Africa Contemporary Record - ACR, London, v. 11, p. B345, 1980.

BAYART, Jean-François. The State in Africa. London: Longman, 1989.

BHAGAVAN, Michael. Angola: prospects for ocialist transformation. Uppsala: Scandinavian Institute of African Studies, 1980.

BIRMINGHAM, David. A short history of modern Angola. London: Hurst, 2015.

BIRMINGHAM, David. Carnival at Luanda. Journal of African History, London, $\mathrm{n}$. 29, p. 93-103, 1988b.

BIRMINGHAM, David. Frontline nationalism in Angola and Mozambique. London: James Currey, 1992.

BIRMINGHAM, David. Angola revisited. Journal of Southern African Studies, London, n. 15, p. 1-14, 1988a.

BITTENCOURT, Marcelo. Dos jornais às armas: trajetórias da contestação Angolana. Lisboa: Vega, 1999. 
BITTENCOURT, Marcelo. Estamos Juntos!: o MPLA e a luta anticolonial - 19611974. Luanda: Kilombelombe, 2008.

BRIDGELAND, Fred. Jonas Savimbi: a key to Africa. London: Hodder \& Stoughton, 1986.

CAHEN, Michel; MESSIANT, Christine. Luttes politiques, tensions sociales et cultures ethniques: Luanda, de la lutte anti-portugaise aux agressions sudAfricaines: introduction. In: CAHEN, Michel (ed.). Bourgs et villes en Afrique Lusophone. Paris: L'Harmattan, 1989. p. 121-124.

CHABAL, Patrick. People's war, state formation and revolution in Africa: a comparative analysis of Mozambique, Guinea-Bissau and Angola. Journal of Commonwealth and Comparative Politics, London, n. 21, p. 104-125, 1983.

CHEYSSON, Claude. Statements produced in 1978. ACR - Africa Contemporary Record, London, v. 11, p. B346, 1980.

CLARENCE-SMITH, GERVASE. Class structure and class struggles in Angola in the 1970s. Journal of Southern African Studies, London, n. 7, p. 109-126, 1980.

CLARENCE-SMITH, Gervase. Le problème ethnique en Angola. In: CHRETIEN, J. P.; PRUNIER, Gerard (eds.). Les Ethnies ont une histoire. Paris: Karmale-AECT, 1989. p. $405-415$.

CONCHIGLIA, Augusta. Angola. Afrique-Asie, Paris, n. 177, p. 23-25, 25 Dec. 1978.

CONSTITUTIONAL LAW. Diário da República, Luanda, Ist series, 31, p. 2, 7 Feb. 1978.

CONSTITUTIONAL LAW. Diary of the Republic, Luanda, Ist series, 11, p. 3, Nov. 1975.

DAVIDSON, Basil. In the eye of the storm, Angola's people. London: Longman, 1972.

DIÁRIO DA REPÚBLICA. Ia série, Luanda, n. 12-45, de Jan. a Dec. 1979.

DIÁRIO DA REPÚBLICA. Ia série, Luanda, n. 79-94, de Nov. a Dec. 1978.

DIAS, Jill. Uma questão de identidade: respostas intelectuais às transformações económicas no seio da elite crioula da Angola Portuguesa entre 1870 e 1930. Revista Internacional de Estudos Africanos, Lisboa, p. 61-93, 1984. 
GABRIEL, Claude. Angola: le tournant africain? Paris: Éditions La Brèche, 1978.

GUIMARÃES, Fernando Andresen. The origins of the Angolan civil war: foreign intervention and domestic political conflict. London: Macmillan Press, 1998.

HEIMER, Franz. Formation sociale, developpement economique et option socialiste en Angola. Genéve-Afrique, Genéve, n. XVIII, p. 31-43, 1980.

HEIMER, Franz. The decolonization conflict in Angola: an essay in political sociology. Geneva: Institut Universitaire de Hautes Études Internationales, 1979.

HEIMER, Franz. W. Educação e sociedade nas áreas rurais de Angola: resultados de um inquérito: apresentação do inquérito, estatísticas descritivas. Luanda: Missão de Inquéritos Agrícolas de Angola, 1972. v. 1.

HENDERSON, Lawrence. Angola, five centuries of conflict. London: Cornell University Press, 1979.

HODGES, Tony. Angola to the 1990's, the potential for recovery: special report no 1079. London: Economist Intelligence Unit, 1987.

LABAN, Michel. Viriato da Cruz: cartas de Pequim. Luanda: Chá de Caxinde, 2003.

LAMB, David. Angola moving to end isolation from the West and dependency on Cubans. Los Angeles Times, Los Angeles, 3 Dec. 1978 a.

LAMB, David. Cuban advisers downgraded; Angola turns pragmatic as economy founders. Herald Tribune, New York, 6 Dec. 1978b.

LEWIS, Flora. Angola. The New York Times, New York, 13 Dec. 1978.

MABEKO-TALI, Jean-Michel. Dissidences et Pouvoir d'État: le MPLA face a luimême (1962-1977). 1996. Thesis. (PhD thesis) - Université Paris VII, Paris, 1996. Tome I.

MARCUM, John. Angola: War Again. Current History, Philadelphia, v. 92, n. 574, p. 218-223, 1993.

MARCUM, John. The Angolan Revolution, volume i, the anatomy of an explosion (1950-1962). Cambridge, Ma: MIT Press, 1969. 
MARCUM, John. The Angolan revolution, volume ii, exile politics and Guerrilla Warfare (1962-1976). Cambridge, Ma: MIT Press, 1978.

MENEZES, Hugo Azancot. Percursos da luta de libertação nacional. Lisboa: Vega, 2017.

MESSIANT, Christine. 1961 - L'Angola coloniale, histoire et société: les prémisses du mouvement nationaliste. Paris: EHESS, thèse de doctorat en sociologie, 1983.

MESSIANT, Christine. 1961 L'Angola colonial, histoire et société: les premises du movement nationaliste. Bâle: Switzerland, 2006.

MESSIANT, Christine. Angola les voies de l'ethnisation et de la décomposition II - transition à la démocratie ou marche à la guerre? l'épanouissement des deux 'partis armés (Mai 1991-Septembre 1992). Lusotopie, Aix-en-Provence, n. 3 , p. 181-221, 1995a.

MESSIANT, Christine. Angola, les voies de l'ethnisation et de la décomposition I - de la guerre à la paix (1975-1991): le conflit armé, les interventions internationales et le peuple angolais. Lusotopie, Aix-en-Provence, n. 1, p. 155210, 1994.

MESSIANT, Christine. Luanda (1945-1961): colonisés, société coloniale et engagement nationaliste. In: CAHEN, Michel (ed.). Bourgs et villes en Afrique Lusophone. Paris: L'Harmattan, p. 125-199, 1989.

MESSIANT, Christine. MPLA et UNITA, processus de paix et logique de guerre. Politique Africaine, Paris, n. 57, p. 40-57, $1995 \mathrm{~b}$.

MEYNS, Peter. O desenvolvimento da economia Angolana a partir da independência: problemas da reconstrução nacional. Revista Internacional de Estudos Africanos, Lisboa, n. 2, p. 121-161, 1984.

MOHANTY, Susanna. Political development and ethnic identity in Africa, a study of Angola since 1960. London: Sangam Books, 1992.

MPLA'S POLITBURO MAY DAY STATEMENT. The Guardian-US, New York, p. 5, 9 May 1979.

OTTAWAY, David. Angola tries new pragmatism; Neto asks for help to repair economy. Herald Tribune, London, p.9, 27 Dec. 1978.

PATRÍCIO, José. Angola: EUA, os caminhos do bom senso. Luanda: Executive Center, 1997. 
PAWSON, Lara. In the name of the people: Angola's forgotten massacre. London: I.B. Tauris, 2014.

PEEL, Quentin. Angola states terms for investors. Financial Times, New York, p. 7, 11 Jul. 1979.

PELISSIER, René. La Colonie du Minotaure. Paris: Éditions Pelissier, 1978.

PRINCIPAIS RESULTADOS DO DESENVOLVIMENTO ECONÓMICO E SOCIAL DA REPÚBLICA POPULAR DE ANGOLA NO TRIÉNIO 1978/1980. In: ORIENTAÇÕES FUNDAMENTAIS PARA O DESENVOLVIMENTO ECONÓMICO E SOCIAL PARA O PERÍODO 1981-1985. Luanda: Publicações MPLA, 1980.

RÁDIO NACIONAL DE ANGOLA broadcast of $17^{\text {th }}$ January 1978. Survey of World Broadcast - SWB, 19 Jan. 1979.

RELATÓRIO DO COMITÉ CENTRAL AO I CONGRESSO DO MPLA. Luanda:

Publicações MPLA, 1977.

RELATÓRIO DO COMITÉ CENTRAL AO I CONGRESSO EXTRAORDINÁRIO DO PARTIDO. Luanda: Publicações MPLA,1980.

RESOLUÇÕES E MENSAGENS DO IO CONGRESSO EXTRAORDINÁRIO DO MPLAPT, Luanda: Publicações MPLA, 1980.

ROCHA, Edmundo; SOARES, Francisco; FERNANDES, Moisés (coord.). Angola:

Viriato da Cruz: o homem e o mito. Luanda: Chá de Caxinde, 2008.

SIMONET, Henry. Angola. The New York Times, New York, p. 5, 18 Sep. 1978.

SOMERVILLE, Keith. Angola: politics, economics and society. London: Frances Pinter, 1986.

SOREMEKUN, Fola. Angola: the road to independence. Nigeria: University of Ife Press, 1983.

VANCE, Cyrus. Statements in June 1978. Africa Contemporary Record - ACR, London, p. B493-B494, 1980. Angola section.

VIDAL, Nuno. A génese da economia do petróleo e dos 'esquemas' impeditivos do desenvolvimento. In: VIDAL, Nuno; ANDRADE, Justino Pinto de (eds.). 
Economia política e desenvolvimento em Angola. Lisboa; Luanda: Chá de Caxinde, 2011. p. 9-66.

VIDAL, Nuno. O MPLA e a governação: entre internacionalismo progressista marxista e pragmatismo liberal-nacionalista. Estudos Ibero-Americanos, Porto Alegre, v. 42, n. 3, p. 815-854, 2016.

VIDAL, Nuno. The Angolan regime and the move to multiparty politics. In: CHABAL, Patrick.; VIDAL, Nuno. (eds.). Angola: the weight of history. London: Hurst, 2007. p. 124-174.

WHEELER, Douglas; PELISSIER, René. Angola. London: Pall Mall Press, 1970.

WOLFERS, Michael; BERGEROL, Jane. Angola in the Frontline. London: Zed Press, 1983.

WRIGHT, George. The destruction of a nation, United States' policy toward Angola since 1945. London: Pluto Press, 1997.

YOUNG, Tom. The politics of development in Angola and Mozambique. African Affairs, Oxford, 87, p. 165-184, 1989.

ZENHA-RELA, Manuel. Angola entre o presente e o futuro. Lisboa: Escher, Agropromotora, 1992. 